\title{
The boy who sewed his lips together in protest
}

\author{
Tony Delamothe deputy editor, The BMJ
}

The former UK prime minister Tony Blair described the Freedom of Information Act 2000 as one of the biggest mistakes of his career. Perhaps history will judge it his greatest legacy, a worthy addendum to the Magna Carta.

Benjamin Dean used the act to force the General Medical Council to disclose secret meetings it had held throughout the Shape of Training review of UK postgraduate medical training, as he explained in his personal view a few weeks ago (doi:10. 1136/bmj.h2400). After the GMC and then the Information Commissioner's Office refused his request for documentation of these meetings, he appealed successfully to the General Regulatory Chamber of the Courts and Tribunals Service. Without his efforts, the issue would have stayed secret. Instead, it's fully aired in our Letters this week (doi:10.1136/bmj.h3139, doi:10.1136/bmj.h3152, doi:10.1136/bmj.h3174, doi:10.1136/ bmj.h3194, doi:10.1136/bmj.h3219).

Secrecy, though, is a hard beast to slay and thrives in conditions where governments have something to hide. When the stakes are high, implications for national security are usually invoked, although rarely convincingly. Australia has recently taken this route with its Border Force Act 2015. As David Berger describes in his personal view, the act gags doctors working in the country's notoriously harsh detention centres for people seeking asylum (doi:10.1136/bmj.h3256). Contravening the act, even by revealing the absence of basic sanitary conditions, may result in a two year prison sentence.

In another personal view the paediatrician David Isaacs describes his recent visit to Nauru, one of the Pacific islands where asylum seekers are detained (doi:10.1136/bmj.h3269). "We saw a 6 year old girl who had tried to strangle herself with a fence tie and a defiant 15 year old boy who sewed his lips together in silent protest," he wrote. On his return he spoke to mainstream media and published his findings in a paediatrics journal, something the Australian government has now moved to block.

He calls on Australian and foreign doctors to boycott working in detention centres. Berger wants a petition calling on the Australian government to repeal this repressive legislation, instead promoting openness, accountability, and protection for whistleblowers.

The UK has been in a funk over providing healthcare to undocumented migrants for years (doi:10.1136/bmj.e924) and in April began a new crackdown on "health tourism." This is apparently motivated by the belief that undocumented migrants come to the UK for healthcare. The charity Doctors of the World UK found this a possibility in about $2.6 \%$ of cases, as Lilana Keith and Ewout van Ginneken report in their feature (doi:10. 1136/bmj.h3056). But that hasn't stopped the government toughening up its eligibility criteria for residence, making the UK an outlier in Europe.

Not everything bad is shrouded in secrecy. The destruction of Nottingham's hospital dermatology service happened in plain sight, which is why an independent review can describe it as "an unmitigated disaster" (doi:10.1136/bmj.h3161). Our senior news editor and long time NHS watcher, Annabel Ferriman, summed it up in a blog: "The NHS is gradually being parcelled up into neat little commercial units that can be run by companies such as Circle, Care UK, Virgin Health, and so on. But when one of these 'nice little earners' is removed from a hospital, the knock-on effect is devastating. Meanwhile, services that can't be bundled up into commercially viable units are being starved of cash. It is a tragedy." (http://blogs.bmj.com/bmj/2015/06/11/ annabel-ferriman-dis-integration-of-the-nhs)

Cite this as: BMJ 2015;350:h3306

๑ BMJ Publishing Group Ltd 2015 